\title{
Proksimal tibia kırıklarında minimal invaziv plaklı osteosentez uygulamaları
}

\author{
Minimal invasive plate osteosynthesis in proximal tibial fractures
}

\author{
Mesut Atabek, Uğur Gönç \\ LIV Hospital, Ortopedi ve Travmatoloji Kliniği, Ankara
}

\begin{abstract}
Son yıllarda proksimal tibia kırıklarının tedavisinde, ortopedik travmatolojideki gelişmelere paralel olarak ilerlemeler mevcuttur. Bu bölge kırıklarının tedavisinde kullanılan değişik tespit yöntemlerinin hepsinin kendine göre avantajı ve dezavantajı bulunmaktadır. Bununla beraber, 90'lı yıllarda geliştirilen kilitli plak-vida sistemleri sayesinde, minimal invaziv girişimler proksimal tibia kırıklarında da popülerlik kazanmıştır. Minimal invaziv girişimlerin yumuşak dokuyu koruyucu etkisi, proksimal tibia kırıklarında özellikle önemlidir. Bu yöntemde kapalı redüksiyon kullanıldığından, yanlış kaynamaları önlemek için indirekt redüksiyon yöntemlerine hakim olmak gerekmektedir. Eklemi ilgilendiren kırıklarda, öncelikle eklemin anatomik redüksiyonu ve stabil tespiti şarttır. Metafiz bölgesindeki parçalı kırık için ise kilitli plaklar ile lateralden submusküler olarak köprüleme uygulanmaktadır. Bu amaçla, proksimal tibia kırıları için özel geliştirilmiş kılavuzlu sistemler mevcuttur. Minimal invaziv plaklama, proksimal tibia kırıklarında daha erken ve iyi kaynama sağlayan ve düşük komplikasyon oranlarına sahip başarılı bir yöntemdir.
\end{abstract}

Anahtar sözcükler: proksimal tibia; plak osteosentezi; minimal invaziv cerrahi

\begin{abstract}
There is an improvement in the treatment of proximal tibial fractures in the recent years due to the new defined concepts in orthopedic traumatology. Different fixation methods can be used in proximal tibia and each method has its own advantages and disadvantages. After the development of locked plates in 1990's, minimal invasive procedures have become popular also in proximal tibial fractures. Protecting the soft tissues with these minimal invasive procedures is particularly important in the proximal tibia region. Since closed reduction is used usually, it is very important to be familiar with the indirect reduction techniques when performing minimal invasive surgery. In intraarticular fractures, first anatomical reduction and stable fixation of the articular surface is mandatory. Then a laterally locked plated is applied submuscularly in order to bridge the comminuted metaphyseal area. Many specially designed locked plates with aiming devices are available for the treatment of proximal tibial fractures with minimal invasive technique. Minimal invasive plate osteosynthesis is a successful treatment method for proximal tibial fractures with high and rapid union rates and low complications.
\end{abstract}

Key words: proximal tibia; plate osteosynthesis; minimal invasive surgery

\section{P}

roksimal tibia kırıkları, proksimal tibia metafizini ilgilendiren, eklem içi ya da eklem dışı olabilen kırıklardır. Bu kırıklar genellikle yüksek enerjili travmalar sonrasında oluşur ve parçalı veya segmenter kırıklar şeklinde karşımıza çıkabilir. Ancak, spor yaralanmaları sonrasında indirekt yaralanma mekanizması ile veya osteoporotik hastalarda basit travmalar ile de oluşabilmektedir. Proksimal 1/3 tibia kırıklarında kuadriseps ve iliotibial bandın deforme edici etkileri yüzünden çoğu zaman valgus ve fleksiyon (apeks anterior) deformitesi gözlenir. Hangi tedavi yöntemi seçilirse seçilsin, proksimal parçanın kısalığı çoğunlukla redüksiyon zorluğuna neden olur.
Bu zorluk ameliyat sonrası dizilim bozukluğu olarak karşımıza çıkabilir. Özellikle deplase kırıklarda, kapaIı redüksiyon ve alçılama diz fonksiyonları açısından yetersiz bir tedavidir. Bu nedenle, proksimal tibia kırıklarında çoğunlukla cerrahi tedavi yöntemleri tercih edilmektedir. Ancak, yüksek enerjili travmalar sonrasında oluşan bu kırıkların cerrahi tedavisi yüksek komplikasyon oranlarına sahiptir. Klasik açık redüksiyon ve plaklama çoğunlukla yumuşak doku problemlerine ve derin enfeksiyona yol açabilmektedir. Sadece lateralden konvansiyonel plaklama yapıldığında, mediyal kolon desteklenmediği için varus çökmesi görülebilir (Şekil 1). ${ }^{[1-5]}$ Eksternal tespit ile tespit sonrası

- Illetişim adresi: Uzm. Dr. Mesut Atabek, LIV Hospital Ankara, Bestekar sokak no: 8, Kavaklıdere, Ankara Tel: 0533 - 3591612 e-posta: mesutatabek@yahoo.com

- Geliş tarihi: 1 Eylül $2018 \quad$ Kabul tarihi: 1 Eylül 2018 


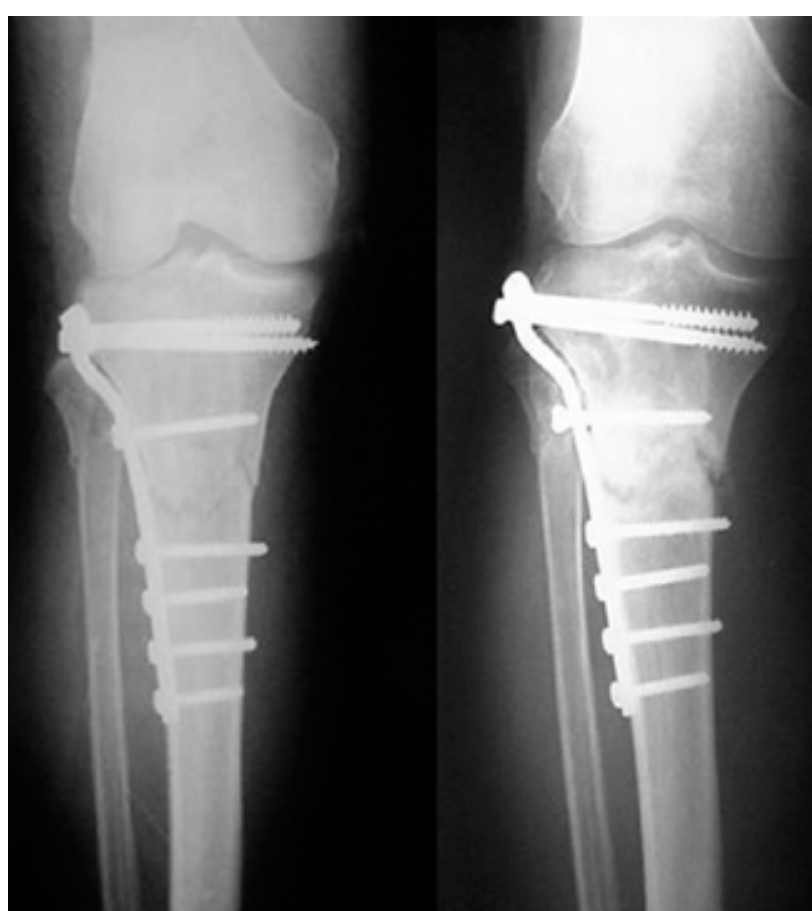

Şekil 1. Lateralden konvansiyonel plak ile yapılan tespit sonrası gelişen varus çökmesi. (Çankaya Ortopedi Grubu arşivinden alınmıştır) pin dibi enfeksiyonları görülebilir ve proksimal tibia metafizine gönderilen teller ekleme yakın yerleşimli olduğu için septik artrit riski oluşturur. ${ }^{[6,7]}$ Proksimal tibia kırıklarında intramedüller çivilemenin de kendine özgü sorunları vardır. İntramedüller çivi ile proksimal parçanın kontrolü zordur ve bu nedenle yanlış kaynama riski yüksektir. ${ }^{[8,9]}$ Kilitli plak-vida sistemlerinin ortopedik travma cerrahisinde sıklıkla kullanılmaya başlanması ile birlikte, proksimal tibia kırıklarında da minimal invaziv plak osteosentezi (MiPO) uygulamaları popüler olmaya başlamıştır. Lateralden yapılan MiPO uygulamalarının, plakların submusküler olarak yerleştirilmesi, kilitli vida kullanımı ile kısa segment proksimal parçanın daha iyi tespit edilebilmesi ve proksimalde sabit açılı vidaların değişik yönlerde uygulanabilmesi gibi avantajları mevcuttur.

\section{ENDIKASYON}

Proksimal tibiada MiPO yöntemi en çok eklem dışı metafiz kırıklarında (AO/OTA Tip 41-A2, A3 kırıklar) tercih edilmektedir (Şekil 2). Eklemi ilgilendiren daha kompleks kırıklarda (AO/OTA Tip 41-C1, C2, C3 veya

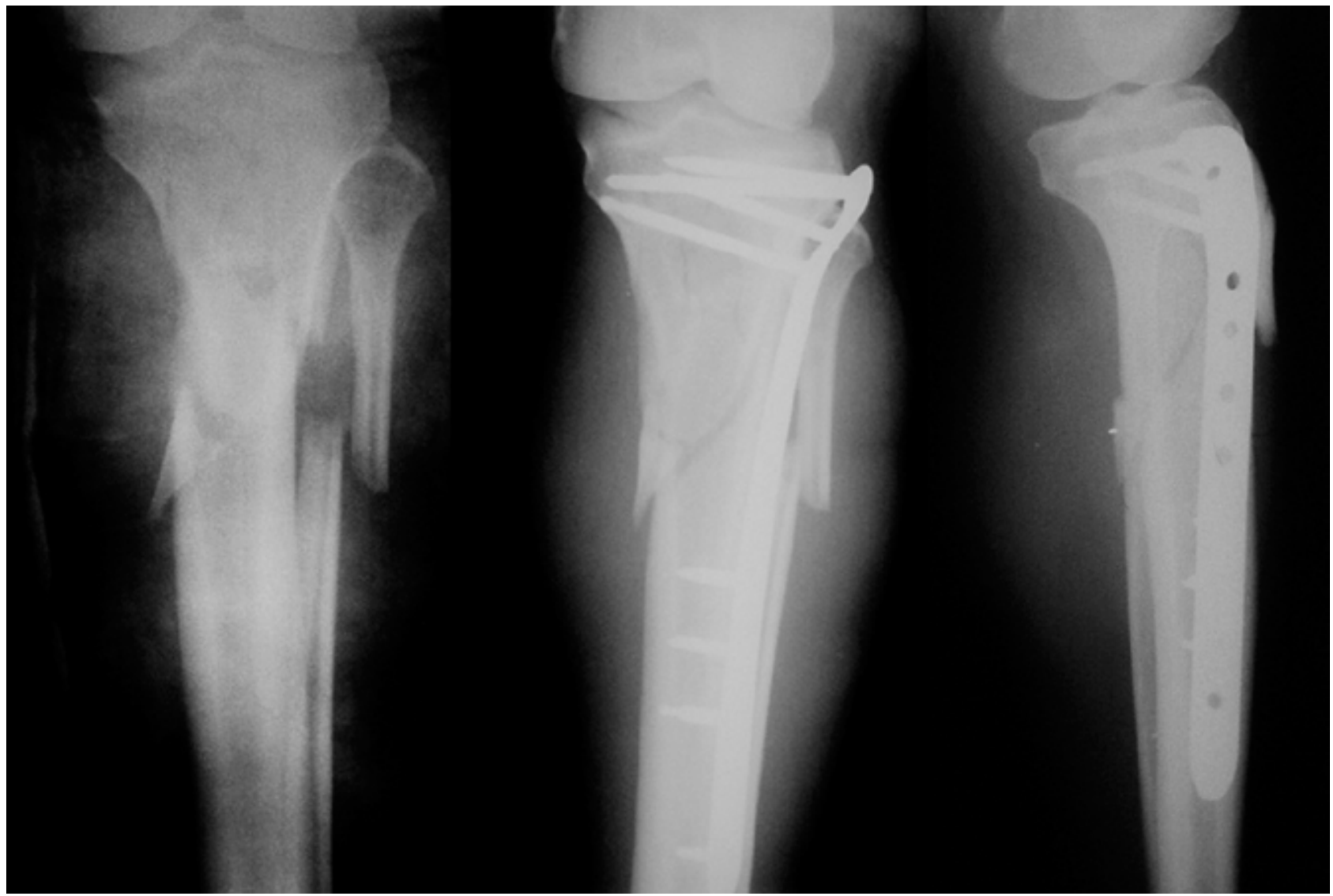

Şekil 2. Eklem dışı AO/OTA tip 41-A3 kırığın lateralden MiPO yöntemi ile tedavisi. (Çankaya Ortopedi Grubu arşivinden alınmıştır) 


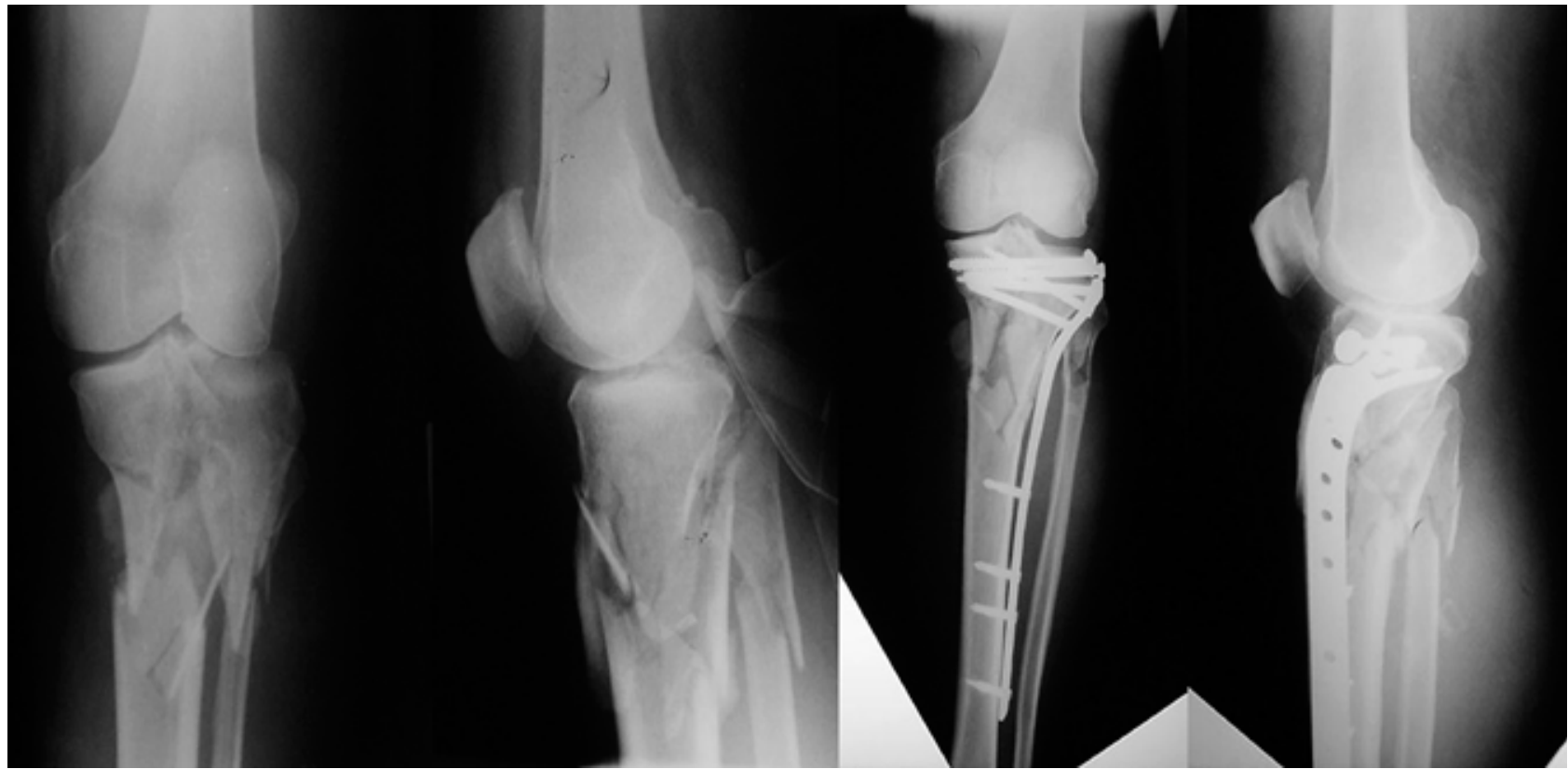

Şekil 3. Eklem içi AO/OTA tip 41-C3 kırı̆̆ın lateralden MiPO yöntemi ile tedavisi. Eklem içi anatomik redüksiyon çektirme vidaları ile sağlandıktan sonra metafiz köprülenmiş. (Çankaya Ortopedi Grubu arşivinden alınmıştır)

Schatzker Tip V, VI kırıklar) ise eklemin anatomik redüksiyonu ve tespiti sonrası metafizdeki parçalı kırık MiPO yöntemi ile köprülenebilir (Şekil 3). Kısmi eklem içi kırıklarda ise (AO/OTA Tip B veya Schatzker Tip I-IV kırıklar) amaç eklemin anatomik redüksiyonu ve kırığın mutlak denge prensiplerine göre tespiti olduğu için genellikle açık redüksiyon ve plak-vida tespiti tercih edilmektedir. Tibia orta cisim kırıklarında MiPO için spesifik bir endikasyon yoktur. Ancak, intramedüller çivilemenin zor olacağı, eklemi ilgilendiren proksimal tibia kırıkları ile beraber cisim kırıklarının beraber olduğu segmenter kırıklarda MiPO yöntemi kullanılabilir.

\section{CERRAHI TEKNIK}

Minival invaziv plaklama öncesinde kırık redüksiyonu sağlanmış olmalıdır. Özellikle kilitli plakların kullanıldığı hastalarda plak kırık redüksiyonu için yardımcı olmaz. Bu tür kilitli implantlar "internal fiksatör" hatta "internal eksternal fiksatör" olarak tanımlanmıştır. ${ }^{[10]}$ $\mathrm{Bu}$ nedenle, tespit öncesi redüksiyonun indirekt yöntemlerle elde edilmesi gerekir. Akut kırıklarda indirekt redüksiyon, genellikle ayak bileğinden yapılan el traksiyonu ile sağlanabilir. Gerektiğinde femoral distraktör, geçici eksternal fiksatör, "joystick" olarak kullanılan Schanz vidaları ya da perkütan olarak kullanılan kırık redüksiyon klempleri gibi yardımcı cihazlar redüksiyon için kullanılabilir.
Proksimal tibia kırıklarında en sık kullanılan kilitli plak-vida sistemi LISS ${ }^{\circledR}$ 'in (Les Invasive Skeletal System, Synthes, Paoli, PA) avantajlarından birisi de lateralden uygulanan bu kilitli plak-vida sisteminin açısal stabilitesinin yüksek olmasıdır (Şekil 4). Bu nedenle, sadece lateralden plaklamanın varus çökmesini önlemekte yeterli olduğu düşünülmektedir, ancak özellikle mediyaldeki kırık çok proksimaldeyse ek mediyal desteğe ihtiyaç olabilir. ${ }^{[10]}$ Cerrahi girişim genellikle radyolüsen masada sırtüstü pozisyonda uygulanır. İnsizyon eklem çizgisinin proksimalinden femur midaksiyel plan ve Gerdy tüberkülünün hemen önünden yaklaşık dört $\mathrm{cm}$ olacak şekilde yapılır (Şekil 5a). Diz altına yükseklik konulması işlemi kolaylaştırır. iliotibial bant proksimale ve distale doğru açılır, fasyal insizyon Gerdy tüberkülünün üstündeki periosta kadar ilerletilir. Eklem dışı metafizer bölge kırıklarında redüksiyon skopi kontrolünde indirekt olarak sağlandıktan sonra plak uygulama kolu yardımı ile submusküler olarak anterior kompartmanın altına gönderilir (Şekil 5b). Plağın pozisyonu, plak elle tibia anterior krestte hissedilerek ve skopi kontrolünde plağın metafizer bölgeye oturduğu görülerek kontrol edilir. Redüksiyonun ön-arka ve yan planlarda skopi altında tekrar kontrol edilmesi sonrasında, plak ve uygulama kolu K-telleri ile geçici olarak kemiğe tespit edilir (Şekil 5c). Bu aşamada ön-arka planda yeterli redüksiyon sağlanamamışsa, plak üzerinden gönderilen kortikal çektirme vidaları veya bazı sistemlerde bulunan 


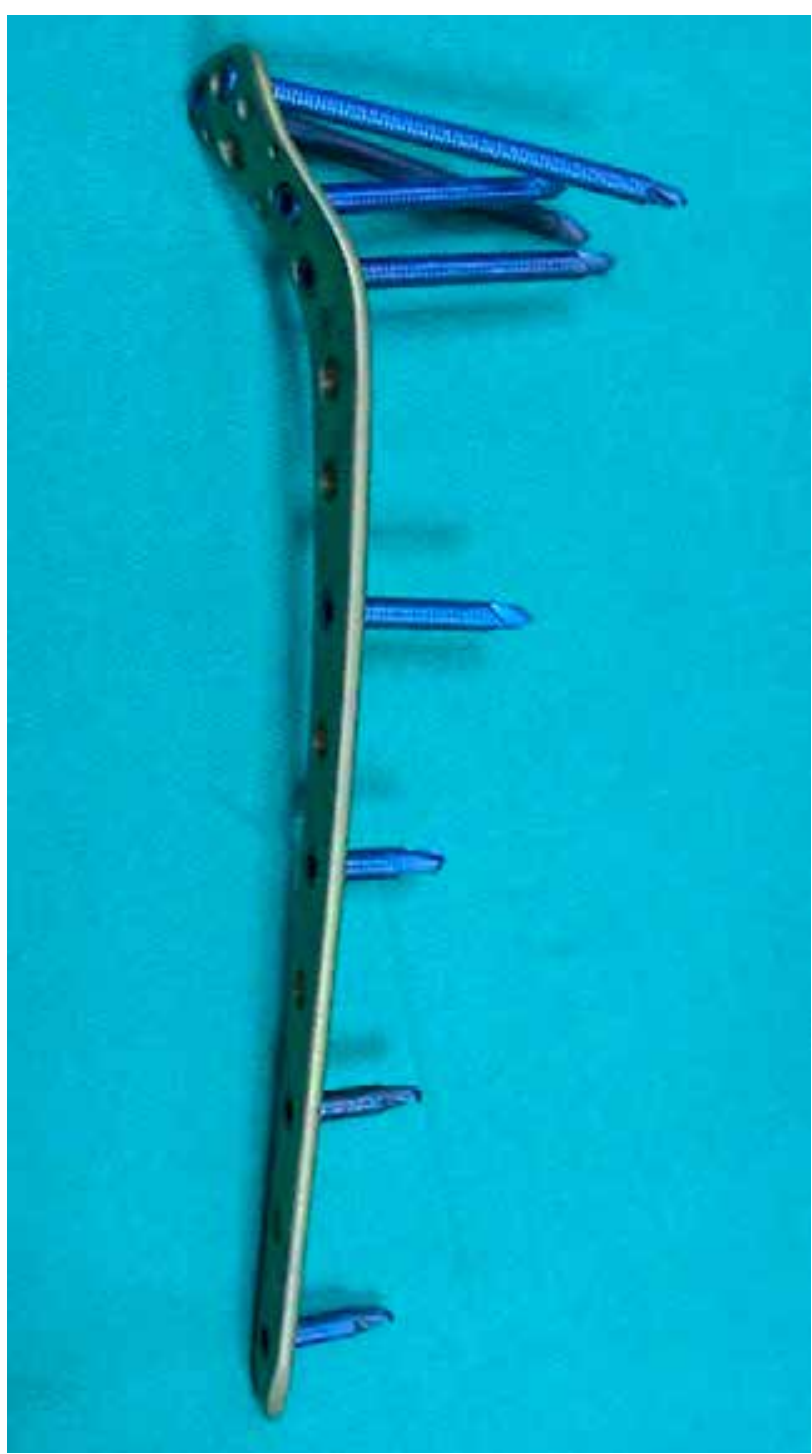

Şekil 4. Proksimal tibiada MiPO yöntemi için kullanılan LISS ${ }^{\circledR}$ (Less Invasive Stabilization System) implantı.

"Whirlybird" çektirme cihazı kullanılarak redüksiyon sağlanabilir. Bu yöntem aynı zamanda plağı kemiğe yaklaştırarak, plağın kemikten çok uzak yerleşimli olmasına bağlı, tespitin stabilitesinin azalmasını da engeller. Ön-arka ve yan planda yeterli redüksiyonun sağlandığından emin olunduktan sonra, proksimal ve distal kilitli vidalar uygun koruyucu kılıflar içinden perkütan olarak yerleştirilir (Şekil 5 d). En distalde özellikle 13 delikli uzun plak kullanilıyorsa, peroneal sinirin yüzeyel dalının ve anterior tibial arterin yaralanma riskine karşı distal vidaların perkütan olarak değil, küçük bir insizyon ile damar sinir yapılar korumaya alınarak yerleştirilmesi önerilmektedir (Şekil 6).
Eklem içi uzanımı olan proksimal tibia kırıklarının tedavisinde metafizer bölge için uygulanacak MiPO öncesinde eklemin anatomik redüksiyonunun ve tespitinin sağlanmış olması gereklidir. LISS ${ }^{\circledR}$ proksimal kilitli vidaları, eklem içi kırıkları desteklemek için kullanılmaz. Bu amaçla, eklem içi kırıklara subkondral olarak yerleştirilen ek çektirme vidaları ile interfragmanter kompresyon uygulanmalıdır (Şekil 7a). Plağın proksimalinde çoğunlukla serbest çektirme vidalarını gönderecek kadar yeterli mesafe kalmaktadır (Şekil 7b). Bu amaçla lateral insizyon uzatılabilir, yaklaşım genişletilebilir ve submeniskal artrotomi yapılabilir. Mediyal platodaki eklem içi sorunlar mediyalden ayrı bir insizyonla giderilebilir ve gerekirse ek mediyal destek plağı kullanılabilir.

\section{Ameliyat Sonrası}

Ameliyat sonrasında çoğunlukla ek bir tespit yöntemine gerek yoktur. Yumuşak doku yaralanmasının şiddetine göre ve ek yaralanmalara bağlı olarak aktif ve pasif olarak diz hareketlerine başlanır. Radyolojik kaynama başladıktan sonra kısmi yük verdirilebilir. Klinik ve radyolojik olarak kaynama sağlandıktan sonra tam yük verdirilir. Tam yük verme genellikle eklemi ilgilendiren kompleks kırıklarda üç ayı bulmaktadır.

\section{KLINIK SONUÇLAR}

Literatür değerlendirildiğinde, proksimal tibia kırıklarının tedavisinde uygulanan MiPO yönteminin, başarı oranları yüksek ve komplikasyon oranları düşük bir yöntem olduğu görülmektedir. Cole ve ark., majör komplikasyon olmadan hastaların \%91'inde kaynama sağlamışlar, ortalama kaynama süresini 12,6 hafta, ortalama diz hareket sınırını $1-122^{\circ}$ olacak şekilde elde etmişlerdir. ${ }^{[11]}$ Stannard ve ark., ortalama 16 . haftada, ortalama $1-127^{\circ}$ diz hareket sınırı ile \%100 kaynama sağlamışlardır. ${ }^{[12]}$ Benzer şekilde Boldin ve ark., ortalama 11 haftada, ortalama $1-123^{\circ}$ diz hareket sınırı ile \%96 kaynama elde etmişlerdir. ${ }^{[13]}$ Ma ve ark., iki aşamalı cerrahi ile tedavi ettikleri açık kırıkları içeren çalışmalarında ortalama 38,6 haftada, ortalama $1-125^{\circ}$ diz hareket sınırı ile \%100 kaynama elde etmişlerdir. ${ }^{[14]}$

MiPO ile tedavi edilmiş serilerde fonksiyonel sonuç değerlendirmesi sadece iki çalışmada kullanılmıştır. Ricci ve ark., 38 hastalık serilerinde ortalama LEM (lower extremity measure) 88 olarak saptamışlardır. ${ }^{[15]}$ Boldin ve ark. ise yaptıkları çalışmada, eklem dışı kırıklarda ortalama HSS (Hospital for Special Surgery) skorunu 88, ortalama diz skorunu 91 ve fonksiyonel skoru 93; eklem içi kırıklarda ise ortalama HSS skorunu 74, ortalama diz skorunu 80 ve fonksiyonel skoru 81 olarak ölçmüşlerdir. ${ }^{[13]}$ Bu sonuçlara göre, MiPO 


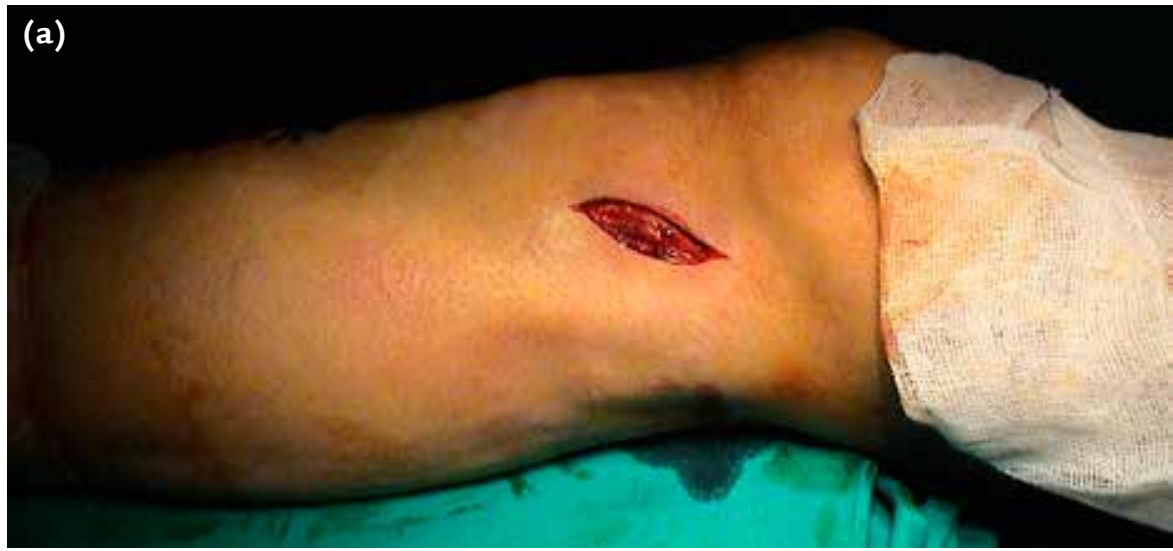

Şekil 5. a-d. LISS $^{\circledR}$ ile MiPO yöntemi cerrahi tekniği: Lateral insizyon (a). Uygulama kolu ile plağın submusküler olarak gönderilmesi (b). Sistemin geçici K-telleri ile kemiğe tespiti (c). Koruyucu kılıflar içerisinden kilitli vidaların perkütan gönderilmesi (d). (Çankaya Ortopedi Grubu arşivinden alınmıştır)
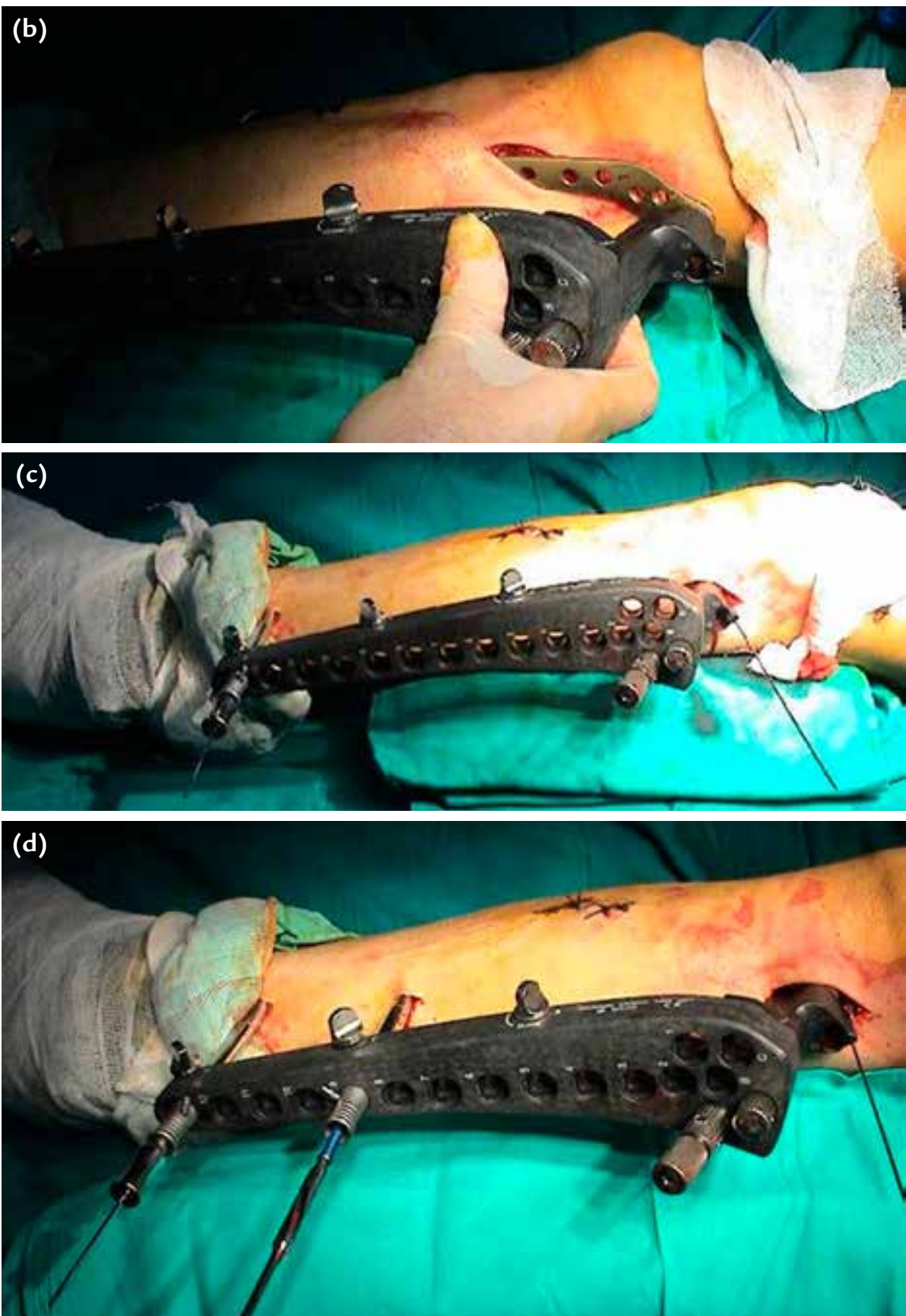


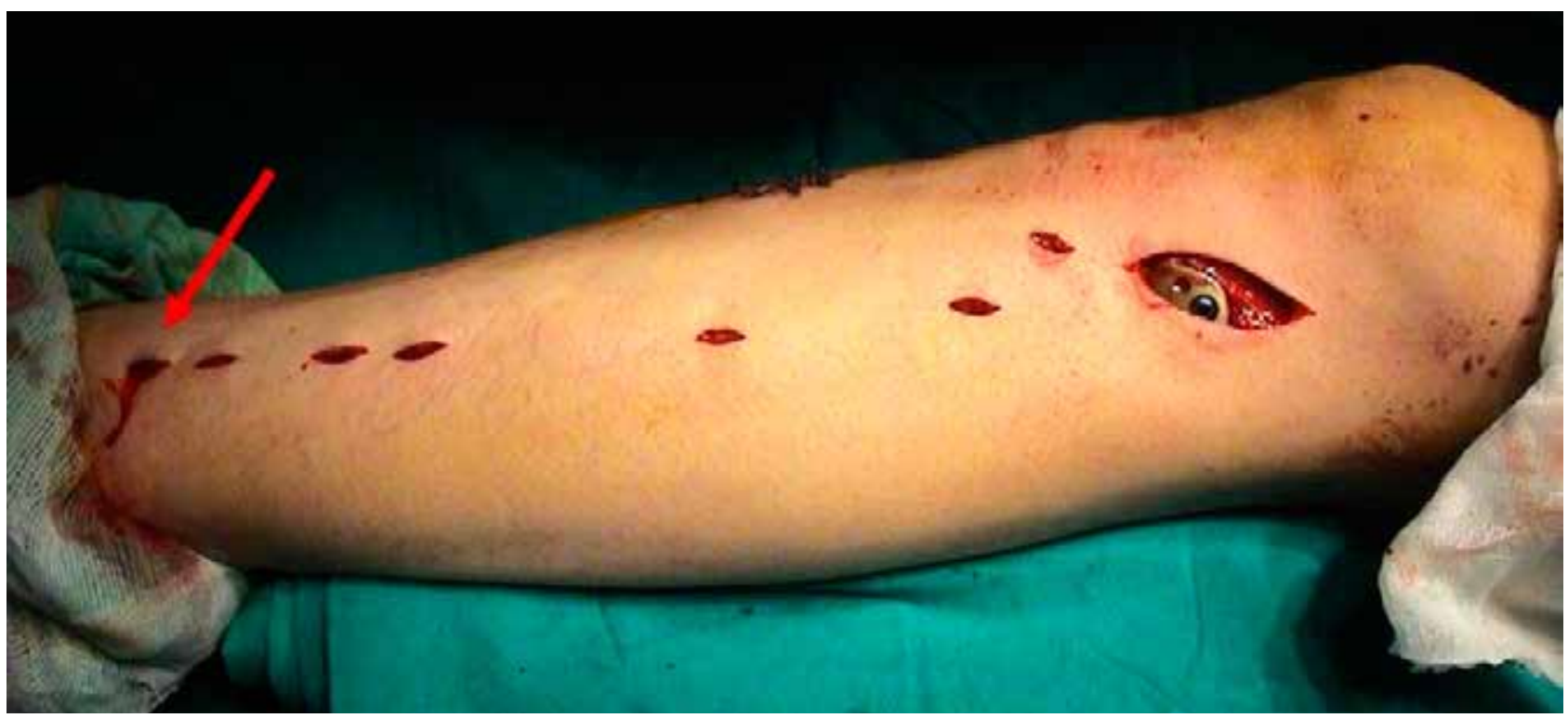

Şekil 6. Uzun plak kullanımında distal vidaların perkütan gönderilmesi damar-sinir yaralanması riski taşır.
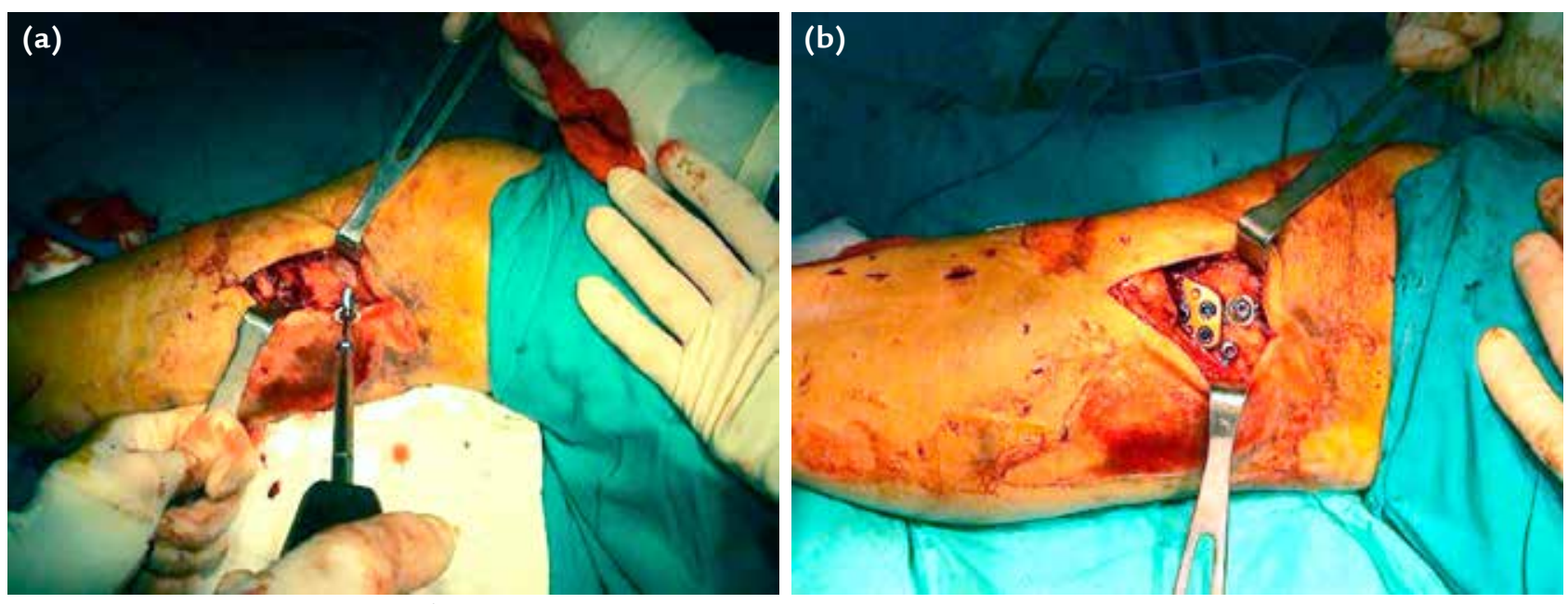

Şekil 7. a, b. Eklem içi kırıklarda MiPO yönteminin uygulanması: Eklem içi kırığın çektirme vidası ile interfragmanter kompresyonu (a). Metafizer bölgeye MiPO uygulandıktan sonra plak ve serbest çektirme vidaları arsındaki ilişki (b). (Çankaya Ortopedi Grubu arşivinden alınmıştır)

yönteminin fonksiyonel sonuçlarının, eklem içi kırıklarda daha düşük olmakla beraber genel olarak oldukça başarılı olduğu görülmektedir.

\section{KOMPLIKASYONLAR}

İndirekt redüksiyon tekniklerindeki zorluk nedeniyle malredüksiyon olasıdır. Ameliyat sırasındaki skopi görüntüleri yanıltıcı olabilir, bu nedenle ameliyat içinde grafi çekilerek değerlendirme yapılması gerekebilir. Cole ve ark. 54 olguluk serilerinde, iki hastada eklem içi malredüksiyon, dört hastada hiperfleksiyon, bir hastada ise varus deformitesi gözlemişlerdir. ${ }^{[10]}$ MiPO yönteminin kullanıldığı serilerde, ameliyat sonrası \%2-20 oranında dizilim bozukluğu tespit edildiği bildirilmiştir. ${ }^{[11,16-18]}$ Yanlış kaynama iki planda olabilir. Varus-valgus dizilim bozukluğunun \%2-13 oranında, rekurvatum-prokurvatum deformitesinin ise \%2-10 oranında gözlendiği bildirilmiştir. [11,12,15,17]

Ameliyat sonrası enfeksiyon, genel olarak yaralanma şiddeti ve ek yumuşak doku travması ile ilgilidir. 
Minimal invaziv yöntemlerle ek cerrahi travma azaldığı için, enfeksiyon oranı açık yöntemlere göre daha azdır. Çalışmaların çoğunda gelişen enfeksiyonlar açık kırıklarla ve majör travmalar ile ilgilidir. Tekniğin üstünlüğü, eksternal tespitin dezavantajları olmadan daha az yumuşak doku travması yaratmasıyla ilgilidir ve literatürde bildirilen enfeksiyon oranları serilerin açık kırıkları içermesine rağmen $\% 0-8$ arasındadır. ${ }^{15,16]}$

Açık kırıklarda tibia proksimaldeki yara genellikle mediyalde görülmektedir. Kırı̆ıın tipine ve yaralanmanın şiddetine göre açık kırıklarda lateralden MiPO uygulaması genellikle başarılı sonuçlara sahiptir. Primer uygulama yapılabildiği gibi iki aşamalı cerrahi tedavi ile eksternal fiksatör tedavisi sonrasında ikinci aşama olarak MiPO yöntemi ile kilitli plaklar kullanılabilir. Açık proksimal tibia kırıklarını içeren 30 olguluk bir seride 24 olguda kaynama elde edilmiştir. Diz fonksiyonları iyi olarak değerlendirilmiş, beş olguda gelişen enfeksiyon implant çıkarılması gerekmeden düzelmiştir. Bu çalışmada, açık kırıklarda yeterli yumuşak doku girişimleri yapıldıktan sonra MiPO yönteminin kabul edilebilir sonuçlara sahip olduğu belirtilmiştir. ${ }^{[18]}$ Literatürdeki serilerin çoğu açık kırıkları da içermektedir ve ciddi enfeksiyon genellikle Tip 3 açık kırıklar ile ilgilidir; açık ve kapalı kırıklar benzer sonuçlara sahiptir. İlginç olarak, aşamalı cerrahi tedavi uygulanan bir seride eksternal fiksatör olarak LISS ${ }^{\circledR}$ kullanılmış, ikinci aşamada yine LISS $^{\circledR}$ ile internal tespit uygulanmış ve sonuçların başarılı olduğu ifade edilmiştir. ${ }^{[14]}$

Minimal invaziv lateral plaklamanın anterior kompartman basıncını arttıracağı yönündeki ilk zamanlardaki endişeler sonucu yapılan bir çalışmada, yöntemin kompartman basıncını arttırmadığı gözlenmiştir. ${ }^{[19]}$ Kompartman sendromlu 28 olgunun incelendiği bir çalışmada, eksternal tespit ve fasyotomi sonrası ikinci aşama olarak LISS ${ }^{\circledR}$ uygulanmış, sadece bir olguda kaynamama gözlenmiştir. Bu çalışmada, bir olguda peroneal sinir lezyonu, bir olguda yanlış kaynama ve bir olguda da osteomiyelit gözlenmiştir. ${ }^{[20]}$

On üç delikli plaklarda 11.-13. deliklere perkütan vida yerleştirme sırasında, yakın komşuluğu nedeniyle superfisiyel peroneal sinir yaralanma riski vardır. Bu bölgede küçük bir insizyon ile açık vidalama önerilmektedir. ${ }^{[21]}$ Yüz dört proksimal tibia kırığının 18'inde 13 delikli plak kullanılmış olan bir çalışmada ve bir olguda sinir lezyonu gözlemlenmiştir. ${ }^{[22]}$ Cole ve ark., 54 olguluk serilerinde görülen iki peroneal sinir lezyonundan birisini iyatrojenik lezyon olarak değerlendirilmişlerdir. ${ }^{[10]}$ Peroneal sinir lezyonun hiç görülmediği seriler de vardır. ${ }^{[13]}$

Schatzker Tip V ve Tip VI gibi kompleks proksimal tibia kırıkların MiPO yöntemi ile tedavisinin başarı oranlarını arttırdığı görülmektedir. Stannard ve ark.'nın
34 olguluk kompleks plato kırı̆ı serisinde, kırıkların hepsinin kaynadığı, derin enfeksiyon gözlenmediği, komplikasyon olarak bir olguda $5^{\circ}$ prokurvatum, bir olguda $4^{\circ}$ valgus geliştiği bildirilmiştir. Yazarlar MiPO yönteminin kompleks kırıklarda da düşük komplikasyon oranlarıyla kullanılabileceğini öne sürmüşlerdir. ${ }^{[12]}$ Benzer başka bir seride de, mediyal destek uygulanmadan MiPO yöntemi ile 38 kompleks proksimal tibia kırığı tedavi edilmiş, olguların 37 tanesi enfeksiyon ve yanlış kaynama olmaksızın iyileşmiştir. ${ }^{[15]}$

İlk yayınlarda MiPO yöntemi ile proksimal tibia kırıklarının tedavisinde yüksek başarı oranları bildirilmesine karşın, düşük de olsa komplikasyonlar mevcuttur. MiPO yöntemi sonrası reoperasyonlar, genellikle implant yetmezlikleri, yetersiz redüksiyon, enfeksiyon, kaynamama ve implant irritasyonuna bağlı implant çıkarılmasıyla ilgilidir. Greftleme ihtiyacı duyulan olgular genelde defektif açık kırıklarla ilgilidir. ${ }^{[23]}$

Cole ve ark., majör komplikasyon olmadan \%91 başarılı sonuç elde ettiklerini bildirdikleri çalışmalarında, komplikasyon olarak iki hastada proksimal tespit kaybı, iki hastada kaynamama, iki hastada derin enfeksiyon ve sekiz hastada dizilim bozukluğu geliştiğini gözlemişlerdir. ${ }^{[11]}$ Yine Schültz ve ark.'nın serisinde, başarı oranı benzer olarak \%91 olarak bildirilmiş, takiplerde bir hastada kaynamama nedeniyle greftleme, bir hastada distal vida yetmezliği nedeniyle vida revizyonu, bir hastada da enfeksiyon nedeniyle debridman uygulanmıştır. Bu seride sadece üç hastada $5-7^{\circ}$ 'lerde varus-valgus dizilim bozukluğu gözlenmiştir. ${ }^{[17]}$ Naik ve ark.'nın 49 olguluk serisinde, koronal veya sagittal planda yaklaşık \%20 yanlış kaynama tespit edilmiştir, ancak bu olgularda fonksiyonel skorlara ve diz eklem hareket açıklığına bakıldığında önemli bir farklılık tespit edilmemiştir. ${ }^{[16]}$

Illk serilerde kilitli vidaların unikortikal olarak kullanılmasına bağlı daha sık görülen implant yetmezliği problemi, vidaların çift korteks yerleştirilmesi ile çoğunlukla giderilmiş görülmektedir. Literatürde tespit kaybı \%0-4 oranında bildirilmektedir. Yazarlar, bu sorunun bir kısmının hasta uyumu ile ilgili olduğunu ve hastaların gerekenden daha önce tam yük vermeleriyle geliştiğini belirtmişlerdir. ${ }^{[11,13]}$ Diz çevresi kırıklarda uygulanan MiPO ile ilgili olarak yapılan bir çalışmada Liu ve ark., implant yetmezliğine bağlı sorunları daha çok distal femur kırıklarında gözlemişlerdir. Vida pull-out riskinin uygun plak pozisyonuyla ilgili olduğunu, bunu elde etmenin tibia proksimalinde daha kolay olduğunu belirtmişlerdir. ${ }^{[13]}$

Proksimalde cilt altında belirginleşen ve diz hareketleri ile rahatsızlık yaratan implantların çıkarılması gerekebilir. Literatürde, olguların \%2-8'inde implant çıkarılması gerektiği bildirilmektedir. ${ }^{[13,20]}$ 
Mediyal ve lateralden çift plaklama ve intramedüller çivileme, biyomekanik olarak minimal invaziv lateral plaklamaya göre primer stabilitede daha iyi görünse $\mathrm{de}^{[24]}$, literatürdeki klinik sonuçlar, minimal invaziv plaklamanın biyolojiye saygılı bir tespit yöntemi olması nedeniyle, iyi sonuçlara sahip olduğunu göstermektedir. Benzer olarak, minimal invaziv girişimler eksternal tespit ile de sağlanabilir. Ancak, eksternal fiksatör tespitinin kendine özgü pin dibi enfeksiyonu, septik artrit riski, rehabilitasyon zorluğu, uzamış kaynama süresi ve hasta uyumu gibi ek sorunları mevcuttur. Bikondiler tibia plato kırıklarında çift plak ve LISS $^{\circledR}$ arasında yapılan karşılaştırmalı tek çalışmada ameliyat sonrası komplikasyonlar benzer oranda bulunmuştur. MiPO yöntemi ile lateral plaklama yapılan grupta yara boyutu ve kan kaybı daha az bulunmuş, ancak dizilim bozukluğu ve semptomatik implant irritasyonu daha fazla gözlenmiştir. Yazarlar, çift plaklama yönteminin uygulamasında daha tecrübeli oldukları için, daha başarılı sonuçlar aldıkları yorumu yapmışlardır. ${ }^{[25]}$

Literatürdeki çalışmalar genelde kısa dönem sonuçlarını sunmaktadır. Boldin ve ark., eklem içi ve eklem dışı kırıkları karşılaştırdıkları çalışmalarında, ortalama üç yıllık takip sonuçlarını bildirmişlerdir. Yazarlar, eklem içi ve eklem dışı kırıkların erken dönem fonksiyonel diz skorlarını benzer olarak tespit etmişler, redüksiyon kaybı olmamakla beraber bir olguda varus malunion gözlemişlerdir. Üç yıllık takip sonunda ise, AO Tip 41 C3.3 kırığı olan iki hastada, ciddi artroz gelişmesi nedeniyle total diz artoplastisi uygulanması gerekmiştir. ${ }^{[13]}$ Yazarlar, eklemi ilgilendiren kompleks kırıkların uzun dönemde sonuçlarının daha kötü olduğunu ifade etmişlerdir.

Birçok çalışmada, hasta serileri hem eklem içi hem de eklem dışı kırıkları, benzer şekilde hem açık hem de kapalı kırıkları içermektedir. Bu durum, sonuçların doğru bir şekilde değerlendirilmesini zorlaştırmaktadır. Sadece eklem dışı kırıkları içeren çalışmalarda, MiPO yöntemi ile yapılan tedavinin, düşük komplikasyon oranları nedeni ile klasik açık redüksiyon ve plaklamaya daha üstün olduğu gösterilmiştir. Collinge ve ark.'ın geriye dönük 14 olguluk serisinde yanlış kaynama tespit edilmemiş, sadece bir hastada osteomiyelit gözlenmiştir. Bu seride, ciddi kemik kaybı olan dört hastaya greftleme gerekmiştir. ${ }^{[23]}$

Krettek ve ark., mediyalde yapılan MiPO yöntemi ile, peroneal sinir lezyonundan kaçınılabileceğini, lateralde kas sıyrılmasının ortadan kaldırılacağını ve uzun plak uygulamasının zorluklarının önüne geçilebileceğini savunmuşlar ve altı olguluk serilerinde başarılı sonuçlar elde ettiklerini bildirmişlerdir. ${ }^{[26]}$ Ancak, günümüzde lateral plak ile MiPO yöntemi hala en sık kullanılan yöntemdir.
Diğer anatomik bölgelerde olduğu gibi, son yıllarda proksimal tibia için de poli-aksiyel kilitli vidaların kullanıldığı yeni implantlar üretilmiştir. Bu özellikteki NCB $\mathrm{PLT}^{\circledR}$ (The Non Contact Bridging Proximal Tibia Plate, Zimmer inc, Warsaw, USA) sistemi kullanılarak tedavi edilen proksimal tibia kırıkları ile ilgili bir çalışmada, \%95 iyi-mükemmel sonuçlar elde edildiği ve komplikasyon oranlarının düşük olduğu bildirilmiştir. ${ }^{[27]}$

Proksimal tibia kırıklarında, tespit yöntemine bakılmaksızın komplikasyon oranları fazladır. Bu komplikasyonlar, kırıkların eklem içi ya da eklem dışı olmasına göre değişmektedir. Özellikle kaynamama ve enfeksiyon gibi komplikasyonlar, genellikle eşlik eden yumuşak doku yaralanmasına bağı gelişir. Kilitli plakların internal fiksatör olarak kullanıldığı MiPO yöntemi ile, kompleks kırıklarda gereksiz yumuşak doku disseksiyonu önlenmektedir. Kilitli plak-vida sistemlerinin kullanılması, biyomekanik olarak avantaj sağlamaktadır. Minimal invaziv plaklama, proksimal tibia kırıklarında iyi kaynama süresi ve düşük enfeksiyon oranlarıyla başarılı sonuçlara sahip bir yöntemdir.

\section{KAYNAKLAR}

1. Blokker $\mathrm{CP}$, Rorabeck $\mathrm{CH}$, Bourne RB. Tibial plateau fractures. An analysis of the results of treatment in 60 patients. Clin Orthop Relat Res 1984;(182):193-9. Crossref

2. Littenberg $B$, Weinstein LP, McCarren $M$, Mead $T$, Swiontkowski MF, Rudicel SA, Heck D. Closed fractures of the tibial shaft. A meta-analysis of three methods of treatment. J Bone Joint Surg Am 1998;80(2):174-83. Crossref

3. Schatzker J, McBroom R, Bruce D. The tibial plateau fracture. The Toronto experience 1968--1975. Clin Orthop Relat Res 1979;(138):94-104.

4. Moore TM, Patzakis MJ, Harvey JP. Tibial plateau fractures: definition, demographics, treatment rationale, and long-term results of closed traction management or operative reduction. J Orthop Trauma 1987;1(2):97-119. Crossref

5. Perry CR, Evans LG, Rice S, Fogarty J, Burdge RE. A new surgical approach to fractures of the lateral tibial plateau. J Bone Joint Surg Am 1984;66(8):1236-40. Crossref

6. Weiner LS, Kelley M, Yang E, Steuer J, Watnick N, Evans M, Bergman $M$. The use of combination internal fixation and hybrid external fixation in severe proximal tibia fractures. J Orthop Trauma 1995;9(3):244-56. Crossref

7. Gaudinez RF, Mallik AR, Szporn M. Hybrid external fixation of comminuted tibial plateau fractures. Clin Orthop Relat Res 1996;328:203-10. Crossref

8. Templeman D, Larson C, Varecka T, Kyle RF. Decision making errors in the use of interlocking tibial nails. Clin Orthop Relat Res 1997;339:65-70. Crossref

9. Lang GJ, Cohen BE, Bosse MJ, Kellam JF. Proximal third tibial shaft fractures. Should they be nailed? Clin Orthop Relat Res 1995;(315):64-74. Crossref

10. Cole PA, Zlowodzki M, Kregor PJ. Less Invasive Stabilization System (LISS) for fractures of the proximal tibia: indications, surgical technique and preliminary results of the UMC Clinical Trial. Injury 2003;34 (Suppl 1):S16-29. Crossref 
11. Cole PA, Zlowodzki M, Kregor PJ. Treatment of proximal tibia fractures using the less invasive stabilization system: surgical experience and early clinical results in 77 fractures. J Orthop Trauma 2004;18(8):528-35. Crossref

12. Stannard JP, Wilson TC, Volgas DA, Alonso JE. The less invasive stabilization system in the treatment of complex fractures of the tibial plateau: short-term results. J Orthop Trauma 2004;18(8):552-8. Crossref

13. Boldin C, Fankhauser F, Hofer HP, Szyszkowitz R. Three-year results ofproximal tibia fractures treated with the LISS. Clin Orthop Relat Res 2006;445:222-9. Crossref

14. Ma CH, Wu CH, Yu SW, Yen CY, Tu YK. Staged external and internal less-invasive stabilisation system plating for open proximal tibial fractures. Injury 2010;41(2):190-6. Crossref

15. Ricci WM, Rudzki JR, Borrelli J Jr. Treatment of complex proximal tibia fractures with the less invasive skeletal stabilization system. J Orthop Trauma 2004;18(8):521-7. Crossref

16. Naik MA, Arora G, Tripathy SK, Sujir P, Rao SK. Clinical and radiological outcome of percutaneous plating in extraarticular proximal tibia fractures: a prospective study. Injury 2013;44(8):1081-6. Crossref

17. Schütz M, Kääb MJ, Haas N. Stabilization of proximal tibial fractures with the LIS-System: early clinical experience in Berlin. Injury 2003;34(Suppl 1):S30-5. Crossref

18. Kim JW, Oh CW, Jung WJ, Kim JS. Minimally invasive plate osteosynthesis for open fractures of the proximal tibia. Clin Orthop Surg 2012;4(4):313-20. Crossref

19. Cole PA, Zlowodzki M, Kregor PJ. Compartment pressures after submuscular fixation of proximal tibia fractures. Injury 2003;34(Suppl 1):S43-6. Crossref
20. Kim JW, Oh CW, Oh JK, Kyung HS, Park KH, Kim HJ, Jung JW, Jung YS. Staged minimally invasive plate osteosynthesis of proximal tibial fractures with acute compartment syndrome. Injury 2017;48(6):1190-1193. Crossref

21. Deangelis JP, Deangelis NA, Anderson R. Anatomy of the superficial peroneal nerve in relation to fixation of tibia fractures with the less invasive stabilization system. J Orthop Trauma 2004;18(8):536-9. Crossref

22. Liu F, Tao R, Cao Y, Wang Y, Zhou Z, Wang H, Gu Y. The role of LISS (less invasive stabilisation system) in the treatment of peri-knee fractures. Injury 2009;40(11):1187-94. Crossref

23. Collinge C, Sanders R, DiPasquale T. Treatment of complex tibial periarticular fractures using percutaneous techniques. Clin Orthop Relat Res 2000;375:69-77. Crossref

24. Lee SM, Oh CW, Oh JK, Kim JW, Lee HJ, Chon CS, Lee BJ, Kyung HS. Biomechanical analysis of operative methods in the treatment of extra-articular fracture of the proximal tibia. Clin Orthop Surg 2014;6(3):312-7. Crossref

25. Jiang R, Luo CF, Wang MC, Yang TY, Zeng BF. A comparative study of Less Invasive Stabilization System (LISS) fixation and two-incision double plating for the treatment of bicondylar tibial plateau fractures. Knee 2008;15(2):139-43. Crossref

26. Krettek C, Gerich T, Miclau T. A minimally invasive medial approach for proximal tibial fractures. Injury 2001;32 (Suppl 1):S4-13. Crossref

27. Jöckel JA, ErhardtJ, Vincenti M, ReissigJ, Hoffmann R, Husain B, Täger G, Partenheimer A, Lill H, Gebhard F, Röderer G. Minimally invasive and open surgical treatment of proximal tibia fractures using a polyaxial locking plate system: a prospective multi-centre study. Int Orthop 2013;37(4):7018. Crossref 